\title{
WOMEN WRITING WOMEN \\ In Lodovico Domenichi's ANTHOLOGY of 1559
}

\author{
GABRIELla SCARLATTA ESCHRICH
}

\begin{abstract}
Summary: In his Rime diverse d'alcune nobilissime et virtuosissime donne (1559), Lodovico Domenichi publishes the poetry of fifty-three women authors across borders of nation, city, politics, religion, profession, class, and genre. Among them, thirty-five dedicate or address their compositions to another woman, thus constructing their own female audience and community. Through the analysis of the sonnets of two well known writers, Veronica Gambara and Vittoria Colonna, and two almost unknown writers, Lucrezia Figliucci and Cassandra Petrucci, this article seeks to establish why and how so many Renaissance women authors dedicated poems to, or addressed another woman author, and how these poems inform our understanding of their authors' relationships. These texts reveal the importance of literary friendships which encouraged and promoted reciprocal admiration and respect, and show that, although these women poets did abide by sixteenth-century conventions of language and imagery, they also drew consciously from each other's writings, following closely each other's cues, style, and preferences, thus establishing a meaningful dialogic mode
\end{abstract}

In his anthology, Rime diverse d'alcune nobilissime et virtuosissime donne, Lodovico Domenichi includes the work of fifty-three women authors and introduces a textual community of female poets whose worth and talents he has been honouring for many years: "Sono gia molti anni passati, ch'essendo Io con lanimo, \& con lopere tutto volto a celebrare quanto per Me si poteva allhora, la nobiltà, \& eccellentia delle Donne" (3). ${ }^{1}$ In this original, ground-breaking volume, Domenichi collects women's poetry and makes it public in a 237-page anthology, a most prestigious genre in sixteenth-century Italy. Published in Lucca in 1559, the collection is a community of women authors created by an advocate and defender of

1 Domenichi (ed.), Rime diverse d'alcune nobilissime, et virtuosissime donne. Subsequent page references to this collection will be incorporated directly into the text. I am very much indebted to Diana Robin for giving me a copy of the anthology as well as some key references. 
women's worth. ${ }^{2}$ In fact, by that year Domenichi had already established his reputation and career as editor and polygraph, collaborating with Lodovico Dolce and Gabriele Giolito on other anthologies, but also as a champion of women, as his Nobiltà delle donne (The Nobility of Women) of 1549 demonstrates. ${ }^{3}$

In the preface to Rime diverse d'alcune nobilissime et virtuosissime donne, Domenichi invites his dedicatee and readers to enter the world of feminine nobility and worthiness, and mostly to enter a new era of women's production of texts. ${ }^{4}$ At the very outset, he establishes within the three pages of his dedication a close-knit community of writers, readers, intellectuals, and sponsors who recognize the worth of women and their literary and intellectual talents, and are willing to collaborate in order to promote them. Domenichi explains how for some time he has been gathering women's poems: "mi posi in un medesimo tempo raunare cio che mi pareva potere procurar loro gloria, e honore" (3; "I decided to put together what I thought could bring them glory and honour") 5 and describes how, in various ways, he succeeded in collecting the poems of 53 women authors. Over the years, he had in fact meticulously and judiciously collected these precious poems from various sources and now he had finally decided to assemble them in a carefully crafted and ordered volume in order to publish them: "Lequali rime sono poi state infino ad hora appresso di Me in quel grado tenute, che le piu care, \& pretiose cose si soglion tenere." (3; "Those poems have been kept by me until now in the same way as one would keep the most cherished and precious things"). Domenichi, however, does not explain how and when he has managed to come to possess so many poems by women. We can just speculate that he gathered some from other anthologies, some of which he edited himself, or from single publications such as the Rime by Vittoria Colonna, and from textual gifts sent to him directly by the authors. ${ }^{6}$ The eclectic manner in

2 For Domenichi's bibliographical information, see Robin, Publishing Women, 5962, both articles by Piéjus, and those of Shemek and Piscini.

3 On Domenichi's career, see Robin Publishing Women, 52 and 262. The five-book The Nobility of Women was directly translated from writers such as Agrippa and Castiglione.

${ }^{4}$ Tomasi argues that Domenichi's decision to print an anthology of women poets demonstrates his ambition to identify and introduce an innovative "product" in the literary and cultural scene, "Alcuni aspetti delle antologie liriche del secondo Cinquecento," 11.

5 All translations are mine.

6 One can also speculate that Domenichi solicited some of the poems. As Cox 
which he brings together his collection is also reflected in the eclectic variety of the authors themselves, who come from diverse backgrounds and geographical regions, as well as the varied themes of their poems, such as love, politics, religion, and praise.

Domenichi remarks on the reasons why he decided to dedicate this volume to a gentleman from Milan, Signor Giannoto Castiglione, rather than to a woman: "son certo, che tutti i meriti, \& leccelentie loro da Lei saranno abbracciati \& graditi senza fine." (5; "I am sure that all their merits and excellent traits will be forever embraced and enjoyed by you"). Moreover, he painstakingly makes it a point to explain why he had not chosen to dedicate the anthology to a lady. In fact, he observes that while these poems written by women should in fact have been dedicated to a woman, as was suggested to him by some friends, he did not want to do so for the right reasons: "non ho però voluto per giuste cagioni seguire in cio il lor consiglio." (4) A list of possible female dedicatees follows: he could have crowned this volume with the names of Signora Lavinia Sanvitale, or Signora Contessa Paola di Beccaria, or her daughter, Signora Livia, or Signora Ottavia Baiarda, or Signora Lucia Sauli, or Signora Lucia Bertana, and finally concludes the list by saying: "Lascio da parte molte principesse, $\&$ Donne d'alto grado, la cui gratia harei potuto sperare d'acquistarmi con cosi nobil dono" (4; "I leave aside many high ranking princesses and women, whose favour I could have hoped to gain with such a noble gift"). Thus, before finally resolving to dedicate his anthology of women's genius and creativity to a man, Domenichi had contemplated several possible female dedicatees. ${ }^{7}$ However, after much consideration, he explains that Castiglione was indeed the best choice because of his connections to other gentlemen who, like him, are mindful and caring of women's poetic abilities: "Percio havendo V.S. con maturo giudicio elettosi la Spagna per istanza di molti anni, \& di continuo usando con gentilissimi cavalieri, \& grandissimi servidori di Donne." (5) This trusted friend would then further their work and best interests among the ranges of sixteenth-century literary and cultural elite in both Italy and Spain, thereby optimizing the authors' accomplishments and reception while also enhancing their editor's

remarks, "there is ample evidence of the close involvement of the poligrafi in enabling and soliciting women's literary production." Women's Writing in Italy, 83.

7 Shemek has argued that Domenichi's choice constitutes a "crack in the editorial façade of feminist advocacy ... for despite Domenichi's insistence on women's merits, male social bonds preclude his squandering this opportunity to curry favor with a powerful man by dedicating his book to a female recipient." "The Collector's Cabinet," 244. 
fame and prestige.

Among the many interesting characteristics of this anthology, the most striking one in my opinion is the frequency in which women address women, or with which women dedicate poetry to other women. Indeed, among the fifty-three women authors across borders of nation, city, politics, religion, profession, class, and genre, thirty-five dedicate or address their compositions to another woman. For example, in the very second page of the anthology, Silvia di Somma, Countess of Bagno addresses her second sonnet to Lavinia Colonna and on the following page, Marguerite de Navarre, sister of King Francis I, dedicates her own poem to Vittoria Colonna. Both Marie-Françoise Piéjus and Deanna Shemek have remarked on this striking characteristic. Shemek writes that some of the poems which bear a dedication in Domenichi's anthology did not include a dedication when they first were published in another venue, ${ }^{8}$ and Piéjus writes that this characteristic is typical only of this anthology. ${ }^{9}$

From the very first pages of the anthology, women poets not only address one another, but also construct their own female audience and community, and imagine more women readers. In other words, women writers and women readers are tightly connected since the beginning in an intimate community governed by a dialogic mode. This aspect triggers an immediate and considerable break from Domenichi's carefully crafted preface, and transgresses his well intended procedure of dedicating his anthology of noble and virtuous women to a male recipient because, as mentioned, a wide number of poems in the anthology are written in honour of, or dedicated to other women authors. Thus, it might appear at first that the preface and the content of the anthology itself are quite at odds with each other, thereby eliciting the reader's surprise and interest. For example, Veronica Gambara and Vittoria Colonna address one another on two occasions (149), and Lucrezia Figliucci addresses her sonnet to Cassandra Petrucci; who in turn answers Figliucci with a tribute sonnet on the same page (19).

Several questions arise. First of all, why and how do so many female authors dedicate poems to, or address another woman author? Is this a distinctive conventional female preference, to address poems to each other, to

8 See Shemek, "The Collector's Cabinet," 246, and Piéjus, "La Première anthologie de poèmes féminins," 202-203.

9 See Piéjus, "La première anthologie," 202, where she notes that there are no dedicatory poems in the anthologies by Dolce (1553) nor Ruscelli (1558), and very few are found in the Ruscelli anthology of 1558. See also her article "Lecture et écriture." 
seek collectivity, community, and sisterhood in the pursuit of literary endeavours? Second, how do these poems inform our understanding of their authors' relationships? As the anthology itself suggests, dedicating or addressing another female writer, friend, mentor, or simply a much admired model becomes an integral and guiding component of the process of writing itself, from beginning to end, and all the way to the finished product in its published form. This practice was indeed common among sixteenth-century writers, especially in Italy and France. One distinctive example is the sonnet exchanges between Veronica Gambara and Vittoria Colonna, which began in 1532, and of which Domenichi reprints two poems. According to Cox, this correspondence "had established an authoritative model for poetic exchange between women."10

Another well known example is Louise Labé who, in her innovative preface to her Euvres of 1555, seeks the support and guidance of Mademoiselle Clémence de Bourges in order to "come out" in public in the company of an educated woman of higher social status. ${ }^{11}$ Furthermore, as Robin extensively shows, Domenichi draws the model for his anthology from Lodovico Dolce's Naples collections (62-63). Thus, I'd like to argue that for early-modern women, the act of writing and creating, and of publishing one's poetry was of course one major accomplishment, but to be able to dedicate it or to address it to another esteemed woman, as if to send it out into the world "in good company," is indeed the coronation of this achievement.

Both Shemek and Piéjus have noted that Domenichi assembled so many poems addressed or dedicated to other women because the woman poet was more easily accepted in the literary world if she was not presented alone, but rather, if she was accompanied and sponsored by a social structure that guaranteed her endeavors and successes, preferably a male structure. ${ }^{12}$ Although by 1559 a large number of works written by women had already been published and circulated, social and cultural constraints

10 Cox, Women's Writing in Italy, 90. See also pp. 74-75 for a detailed account of Colonna's and Gambara's poetry transmission and exchanges.

11 Labé writes in her dedicatory preface to Mlle de Bourges: "And because women do not willingly appear alone in public, I have chosen you to serve as my guide, dedicating this little work to you"; Euvres complètes, 150 (translation mine). For critical work on dedications from women authors to other women, see Rigolot, Larsen, and Losse.

12 See Shemek, "The Collector's Cabinet," 241, and Piéjus, "La Création au féminin," 81. 
were still at work against women's full acceptance and recognition of their literary capabilities. ${ }^{13}$ Thus, Domenichi is particularly careful to plead for the appreciation of his authors' poems with Giannoto. In his compelling preface, the Italian editor powerfully and convincingly frames the reasons why these women writers should and will be read, and their work valued accordingly. His words present his anthology in a way that leaves the receiver little doubt as to how to appreciate this literary gift. It is noteworthy that, as Piéjus explains, it was rare to see dedications in sixteenth-century multi-authored anthologies, while it was very common, as already discussed, to find dedicatory prefaces in single-authored collections. ${ }^{14}$

The many circles of women addressing women in the anthology, labelled by Piéjus and subsequently by Robin with the term réseaux, that is a network of friends who dedicate a poem or a cluster of poems to one another, ${ }^{15}$ inform us not only on the practices of sixteenth-century anthologies, but also on the personal relationships that women writers cultivated with other women writers, an important aspect of Italian cultural history. Indeed, the many réseaux scattered in the anthology embody as well the dialogic tradition of women addressing women, that is, the act of seeking and engaging each other's attention and conversation. As in many Renaissance dialogues by women, as we shall soon see, this interchange became the result of relationships and friendships which, in turn, directly engages the reader deep in their conversation. ${ }^{16}$

As in a dialogue with a trusted friend, Domenichi's anthology stages the perfect textual space where women are freer and more at ease to relate and bond with their interlocutor, thereby creating skilful and passionate verses. Moreover, these clusters of poems demonstrate the author's desire for female models, the acknowledgement and validation of female readership and friendship. What Janet Levarie Smarr remarks about the Renaissance dialogue can be claimed about the authors included in the

13 For example Vittoria Colonna's Rime (1538), Tullia d'Aragona's Rime (1547), and Gaspara Stampa's Rime (1554).

14 Piéjus explains that the predominance of the dedicatory mode marks this anthology as different from Giolito's and Dolce's anthologies prior to 1551, see "La première anthologie," 203.

15 See Piéjus, "La Première anthologie," 203, and Robin, Publishing Women, 62.

16 Smarr, Joining the Conversation, 30, illustrates the characteristics of dialogic relationships in Renaissance texts, characteristics which are also found in the clusters of poems of the 1559 anthology. 
anthology, who themselves noted and appreciated Domenichi's great contribution in providing this opportunity. Smarr remarks: "By including women, addressing women, and acknowledging or borrowing from other women writers, by expressing awareness of their own situation as women, these writers show that women were not always seeking only the models and the audience of men." (Joining the Conversation, 239)

The dialogic mode of Domenichi's anthology bears as well other characteristics of the Renaissance dialogue, because it casts women's writings as a personal and intimate conversation taking place in the substantial textual confines of the anthology, which had been created, defined, and overseen by the editor himself. Several authors, as we shall see more closely in the sonnets analyzed, start and carry on a conversation on a particular subject, thus mirroring the cultivated conversations taking place in Renaissance literary circles across Italy, France, and England. ${ }^{17}$ By dedicating poems to other women, the authors invite the recipients to join in the conversation. This invitation and encouragement materialize into a women's intellectual community of its own, where writers become readers, and readers become writers, and where both invite more readers to join in. Moreover, some of the poems in the collection appear uninhibited by any anxiety of influence, as their authors seek to rework or echo their predecessors, other women writers, or the author with whom they are exchanging poems. The réseaux thus represent a space in which early modern women writers gained considerable literary validation and rewards in addressing one another, and in adopting each other as role models.

Although in his role as collector, editor, sponsor, and benefactor Domenichi is in principle the guide for the fifty-three authors, those who chose to dedicate or address poems to another female author and those who wished to respond are openly and candidly carving their own community within the covers of the anthology, by themselves and for themselves, and by extension for a wider male and female readership. By electing to connect with another woman author, an intellectual "soul mate," the process of writing, and its reception become undoubtedly more rewarding for both participants. Thus, the writers themselves become the enablers of this fruitful and pleasurable literary endeavour, in which networking and socializing become contributing and rewarding factors. Domenichi's contribution to this fruitful conversation is the anthology itself, where the many women's literary and intellectual interests in each other are assembled and emphasized. ${ }^{18}$ Again, the result is a more powerful poetic envi-

17 See Campbell, Literary Circles, 11.

18 Exchanges between elite women already existed. Gambara's and Colonna's son- 
ronment within a well defined and well established context, and the sense of collectivity thereby crafted is clearly identifiable from the first pages.

The source of energy that the various réseaux generate and sustain, by addressing, dedicating, and responding to poems, carefully collected, placed, and alternated throughout the 237 pages of the anthology, seems to me the main answer to why many authors dedicate their work or address it to another woman author. In fact, this continuous energy constructs and sustains a particular literary identity, which is not a single and lonely entity, but rather one that exists in relation to other authors and to their poems or group of poems, thus engendering new and countless opportunities as well as many circles of readers. This anthology, which literally and literarily binds together writers who share poetic, cultural, and personal affinities, offered them, especially to those less known, and their readers a privileged and unique chance to be part of a more established group of poets, and to be published as a coherent group, in cooperation and company of other fellow writers, in the first ever anthology of women, especially because traditionally women have had a more difficult time crossing the threshold from private to public. ${ }^{19}$ It is a very important moment in history for early women poets, and Domenichi's understanding of these particular circumstances as experienced editor, polygraph, and collector of women's verses undoubtedly capitalized on these cultural and historical opportunities.

The sonnets which we will analyze show that women were indeed reading other women and imitating or drawing inspiration from one another. They also express, each in their own style and language, a desire and passion for female models, for female approbation and friendship. They inform the reader of the distinct ties that unite them, whether it is literary fame, complete admiration, pure veneration, or comradeship and familiarity with either the author or her work.

Let us now turn to two poems from an eminent exchange in the anthology, where Veronica Gambara (1485-1550) addresses Vittoria Colonna (1492-1547), and subsequently, Colonna responds to Gambara. Gambara addresses two of her 24 sonnets to Colonna, and so does Colonna, who has 26 sonnets in the anthology.20 Both writers had published extensively in

net exchanges, as mentioned, date from 1532. Another significant correspondence is between Colonna and Marguerite de Navarre. See Brundin on Colonna, and Ferrero/Müller on their letters.

19 On the publication of anthologies, see Clubb/Clubb, Cerrrón Puga, Robin, and Tomasi.

20 It is to be noted that in the anthology Lucia Bertana dell'Oro addresses one panegyric sonnet to both Colonna and Gambara praising their fame and glory. 
anthologies and both had much in common. ${ }^{21}$ All four sonnets appear on the first and second page of Gambara's section (pages 149 and 150); it is therefore evident that Domenichi wanted to give them front stage in the order of both authors' contribution to his anthology. ${ }^{22}$ The first verses of the poems use the very same rhyme word, and all subsequent verses echo similar imagery and corresponding language, including the pun on the name Vittoria. It is as if the sonnet-response becomes a reflection of the first sonnet written by Gambara. Each author constructs an exegi monumentum to the other, thus producing fame and immortality for both. In fact, the themes of glory, memory, victory, eternity, virtue, admiration and eternal love intertwine in both sonnets, revisiting the Petrarchan tradition and the topos of celebrity and immortality with befitting female voices:

Della Signora Verónica Gambara di Correggio alla Marchesa di Pescara

Risposta della Marchesa

O de la nostra etate unica gloria, Donna saggia, leggiadra, anzi divina Alla quale reverente hoggi s'inchina Chiunque è degna di famosa historia.

Ben sia eterna di Voi qua giu memoria, $\mathrm{Ne}$ potrà il tempo con la sua ruina, Far del bel nome vostro empia rapina; Ma di Lui porterete alma vittoria

Il sesso nostro un sacro, \& nobil tempio Dovria, come fia a Palla, e Febo, farvi Di ricchi marmi, e di finissim'oro.

E poiche di virtu siete l'esempio Vorrei, Donna, poter tanto lodarvi, Quanto Io vi riverisco, amo, $\&$ adoro.
Di nuovo il cielo de lantica gloria Orna la nostra etade, \& sua ruina Prescrive, poscia che tra Noi destina Spirto, c'ha di beltà doppia vittoria. Di Voi, ben digna d'immortale historia, Bella Donna ragiono, a cui s'inchina, Chi piu di bello ottiene, \& la divina Interna parte vince ogni memoria.

Faranvi i chiari spirti eterno tempio; La carta il marmo sia, l'inchiostro l'oro, Chel ver costringe lor sempre a lodarvi.

Morte col primo, o col secondo, \& empio Morso, il tempo, non ponno homai levarvi D'immortal fama il bel ricco thesoro.

(Rime d'alcune donne, 149)

Especially meaningful is the last tercet of the sonnet: "Queste alme illustri, son cagion, ch'ogni arte / Tento, per torre alla mia luce l'ombra, / Sol perche al mondo un di si mostri chiara." Domenichi, Rime d'alcune donne, 112. Bertani also addresses another sonnet to Gambara, at p. 114.

21 They were both well educated, from noble and powerful families, and politically and socially well-connected. They were both married to important men and both widowed at a young age. They never remarried, and cultivated their art, friendships (they shared a friendship with important figures such as Bembo), and aspirations. For more bibliographical data on Gambara, see her Rime, Poss, and Cox; on Colonna, see her Rime, her Carteggio, Brundin, Gibaldi, and Cox.

22 Colonna’s twenty-four other sonnets are printed on pp. 206-217. 
Gambara's last verse is a lot less restrained and direct than Colonna's poem altogether, revealing a deep respect, reverence, but also love and adoration: "I would like, Lady, to praise you / as much as I revere, love and adore you." Gambara's feelings for Colonna embody the main theme of her sonnet, and her last tercet becomes increasingly powerful and erotic in both a literary and spiritual manner. Konrad Eisenbichler in his article "Laudomia Forteguerri Loves Margaret of Austria," analyzes Forteguerri's five sonnets written to Margaret of Austria that were also included in Domenichi's anthology. He convincingly argues that, although Forteguerri's love for Margaret is articulated along the lines of traditional Italian lyric poetry and uses Petrarchan language and imagery (285), the poet freely expresses her feelings and same-sex desire, thereby creating a "sensual frisson." (279)23 An undeniable frisson can be perceived as well in Gambara's sonnet for Colonna, in the form perhaps of spiritual and intellectual desire, as she strongly articulates her emotions and passion for her beloved poet and friend.

Her wish is to make known, through the means of her poetry, the magnitude of her love and adoration. From the start, Gambara sings Colonna's unique and exceptional glory ("unica Gloria"), and calls on her own sex to celebrate Colonna's talent ("Il sesso nostro un sacro, \& nobil tempio / Dovria ... farvi"), as if to distinguish women as a more powerful and appreciative group, hereby entreated to immortalize Colonna's achievements. Moreover, she presents Colonna as an exemplum of virtue, in very specific terms "E poiche di virtu siete l'esempio," but also of poetic genius, a topos present throughout the entire sonnet. The powerful language and strong imagery convincingly celebrate Colonna's literary talents and female worth and integrity. By extension, all women should revere, love, and adore the marchioness. The feelings so vividly expressed in the last wish of the sonnet, "Vorrei, Donna, poter tanto lodarvi," are a sincere and deep desire for Gambara herself to be able to sing praises to another woman poet, and to properly and skilfully use her own lyric talents. Shemek notes that dedications sometimes served "to connect women poets among themselves and to cast their writing as a form of correspondence or private conversation, a more limited and more socially acceptable framework for women's writing in the period." (247) Moreover, I would argue as well that this all inclusive feminine collection provides a more suitable space for the exchange of poetry: women writers are here in the company of a trusted friend, therefore they feel more at ease to speak honestly and candidly.

23 See Eisenbichler, "Laudomia Forteguerri Loves Margaret of Austria." 
Colonna's response, although more restrained, expresses in turn her own admiration for Gambara's accomplishments. Some key words are found in both sonnets, such as gloria, nostra etade, vittoria, di Voi, historia, memoria, tempio, marmo, oro, and lodarvi. Colonna's social, cultural, and literary status validates Gambara and her sonnet, and underscores the importance of their friendship, which transpires throughout the sonnets. The act of addressing one another is acknowledged and appreciated by both authors, and the reciprocal admiration casts the sonnets as being closely interconnected. Such intimate conversation could mostly be possible in a private setting or in written form, settings both provided by Domenichi's anthology, who seemed to be able to grasp the importance of female relationships and bonds throughout the peninsula. According to Robin in fact, Domenichi wanted to demonstrate that a "vibrant culture of intellectual women" existed in most Italian cities (51). Both praise sonnets succeed in advertising their authors' connection and friendship, their admiration for each other, as well as their literary skills capable of creating a poem using conventional language and imagery, therefore well in accordance with the sixteenth-century Italian literary tradition and expectations.

In comparison to other women authors, Gambara and Colonna contribute a large number of poems to the volume as a whole, undoubtedly because of their well established fame as both gifted writers and "virtuous and noble" ladies. ${ }^{24}$ Both authors were highly admired throughout the Renaissance and both had mentoring roles. According to Laura Anna Stortoni, Gambara "was highly regarded by Vittoria Colonna, for whom she served as a role model both for her style of life and for her literary work" (24). Cox has recently illustrated the tight bond between the two women writers, as well as their tremendous impact on sixteenth-century Italian literary culture. She convincingly argues that: "The pairing of Colonna and Gambara, and their twin 'canonization,' was critical to the literary dynamics of Petrarchism in its formative periods." 25 Moreover, Colonna was a great role model for many women. Joseph Gibaldi claims that she was an influential intellectual leader, "a friend and adviser to many of the greatest personalities of her age, and an outstanding poet admired and respected by her

24 Both Colonna's and Gambara's poetry had already been anthologized, and Colonna's Rime was published in 1544 and 1552. See Gibaldi for a detailed biography of Colonna, and Poss and Russell for Gambara's.

25 For an extensive discussion on the relationship between Colonna and Gambara and their sonnet exchanges, see Cox, Women's Writing in Italy, 67-76, and Jones, The Currency of Eros, 34. 
contemporaries" (23). These friendships and mutual admiration were central to women authors and their aspirations, as was Colonna's and Gambara's correspondence with many contemporary male writers and artists, and these poetic exchanges were to benefit both. These two poems, as well as the two that we shall analyze next, clearly fit in the pre-existing cultural and literary Cinquecento tradition, but mostly within crucial dialogues of women poets that span across the peninsula. Cox underlines the importance of this particular poetic exchange between women and identifies it as "an authoritative model" because of the social, moral, and political standing of the two poets (Women's Writing in Italy, 90).

Nested by Domenichi in this intimate conversation among women, the poetic female voice becomes passionate and multifaceted. It unveils as well reciprocal admiration, which in turn enlightens women's writings and guides them throughout their literary career. Furthermore, since these poems are addressed by women to other women, the speakers are more at liberty to set their own agenda, and to converse freely with each other without much scrutiny, because their editor had already carved a space for this dialogue to take place and form. Once again, we can draw parallels with Renaissance dialogues because here, too, women express the desire to discover, admire, and imitate female models. Smarr explains that "They [the women] desired not only inclusion in a male world but also the representation of a female world where ... women converse among themselves and bring these women's conversation to a wider public. In sum, most of these women envision their work circulating in a society where both men and women read and where both male and female alliances offer important support." (239)

Friendship and mutual admiration pervade as well the next two sonnets composed by much less renowned writers. Lucrezia Figliucci writes to Cassandra Petrucci and, in turn, Petrucci answers Figliucci. Domenichi again places both poems on the same page, at the beginning of Figliucci's series of poems and almost at the very beginning of his anthology. $\mathrm{He}$ includes as well eleven sonnets, one canzone, and one short poem by Petrucci, and six sonnets by Figliucci, including the following one addressed to Petrucci. This positioning seems to suggest a noteworthy intention to cast the writers' unlimited admiration for each other and true longing for a female dialogue which is characterized by candid honesty and deep passion. This is indeed a feature which Domenichi seems to underscore throughout his volume: open and honest interest in the writers' reciprocal work. The theme of the poems is admiration, praise and encouragement by both poets, and in equal measure. Petrucci's sonnet is extreme- 
ly similar to Figliucci's, as each rhyme is the same, and many of the same words are borrowed to form similar images. Indeed, strong similarities in language, imagery and feelings seem to pervade both poems.

Di M. Lucretia Figliucci

Mad. Cassandra Petrucci

Quella chiara virtu, che da primi anni In Voi destò leggiadri, \& vaghi fiori, Rende frutti hor, ch'a piu pregiati allori Non pure invidia fan, ma scorni, \& dann

Onde spiegando al ciel sicura i vanni, Fate che lieto ogniun v'ame, $\&$ honori; Cosi fregiata de piu degni honori Far procacciare a morte oltraggi, e inganni.

Sia non posso arrivare al vostro volo; Che troppo adombra questa bassa spoglia Quel bel, che lalma in ciel conobbe prima.

Pur con l'esempio vostro i mi consolo, Et cerco alzarmi a lalta cagion prima; Ma il sapere aguagliar non puo la voglia.
Risposta (by Petrucci)

Quanto felici in Voi sieno i lieti anni,

Et quanto meritate i vaghi fiori,

Hora ogniun vede i gia pregiati allori

Son sbigottiti pe' veduti danni:

A tal che lieta co bei vostri vanni

Al ciel salite, \& di celesti honori

V'ornate si, che questi bassi chori

. Pregiate a vile, \& gli tenete inganni.

Dovunque va l'altiero vostro volo,

Che l'indirizzi l'honorata spoglia

Sembra quel bel, che in ciel si vede prima.

Ond'Io con allegrezza mi consolo,

Veder Voi con Apollo esser la prima:

Ne brama altro, che questo la mia voglia.

(Rime d'alcune donne, 19)

Figliucci's first line seems to echo the title of the anthology itself as virtue is attributed to Petrucci as her first quality and finest accomplishment. Both poems develop the traditional topos of the sixteenth-century woman of virtue and intellect, a virtue cultivated by Petrucci from the very beginning of her life and which now bears literary laurels, a key topos of the Petrarchan tradition. Figliucci wishes for everybody to love and honour her beloved friend, because she is indeed worthy. The first tercet displays her own modesty in attempting literary heights: "non posso arrivare al vostro volo" ("I can't reach your flight") to which Petrucci responds with a reassuring verse: "Dovunque va l'altiero vostro volo" ("Wherever your soaring flight might go"). Both tercets are infused with Neoplatonism and demonstrate the authors' education in both classical and contemporary literature. Although not in such large scale as in Gambara's and Colonna's sonnets, fame is very much in the minds of Figliucci and Petrucci as well. Modesty is more substantial in these two sonnets than in the previous two poems, perhaps because of their more modest literary presence in cultural circles. Nonetheless, both poets intend to contribute to each other's fame by singing each other's praises. Jones remarks that these types of profitable exchanges between authors contribute to the building of a positive literary reputation and to the importance of the construction of a public self as writer. ${ }^{26}$ Just like Gambara, Figliucci claims that her friend is an exemplum 
which consoles her and gives her hope and, like Gambara, she seeks encouragement which she easily finds in her friend and in her accomplishments. Moreover, Figliucci obtains in her role model a reason to better herself and her art: "Et cerco alzarmi a lalta cagion prima." (I seek to elevate my highest reason"). In her response, Petrucci finds comfort and support in her friend's literary endeavours as well, and praises her as "la prima," the best in Apollo's art. Petrucci ends her poem with a very strong claim, "Ne brama altro, che questo la mia voglia," ("My will only longs for this"), a passionate verse which skilfully summarizes both sonnets.

Not much is known of these two writers, but we do know that both were from Siena. Cassandra Petrucci appears in Maria Bandini Buti's catalogue of women writers as a relative of Aurelia Petrucci, whose poetry is also included in Domenichi's anthology (130). Even less is known about Aurelia Figliucci, a member of an influential Sienese family. ${ }^{27}$ However, much is learnt from the sonnets because personal details of both are revealed, especially their admiration for each other, their love for the art of writing, their pride in belonging to a community of letters, and their longing for mutual admiration and encouragement. Finally, these sonnets are very closely linked in language, images and metaphors, and all rhymes match. Moreover, although their ideas are developed in a slightly different fashion, the meaning and theme of both sonnets are extraordinarily similar: "vaghi fiori, pregiati allori, mi consolo, etc..." allowing very few variations.

The first conclusion I would like to draw, is that these texts reveal the importance of female friendship which encouraged and promoted reciprocal admiration and respect, a friendship which is present throughout the anthology. As Robin observed, Domenichi's anthology indeed demon-

26 See Jones, The Currency of Eros, 8, as well as her article "Surprising Fame," in which Jones claims: "The solitary poet goes unread; the famous poet is socially constituted, invented through the gaze, the commentary, the assessment of others." (92).

27 I want to thank Konrad Eisenbichler who has graciously shared with me his knowledge about Figliucci. He writes about her in his forthcoming book: The Sword and the Pen: Women, Politics, and Poetry in Sixteenth-Century Siena. He notes that very little biographical data is known about Figliucci, not even her date of birth. However, the sonnet exchange with Petrucci certifies to the two women's friendship and connection, and as Eisenbichler argues, this connection needs to be researched further. 
strates a tradition of female literary friendships in Italy (151), and all four poems persuasively testify to this tradition. Furthermore, they prove that these women authors can draw consciously from each other's writings, as much as from earlier or contemporary men's work, as they follow closely each other's cues, style and preferences in the way imitatio and dispositio are played out. This demonstrates a strong dialogic impulse, and an enthusiasm to engage directly, intimately and passionately with the interlocutor. The remarkable friendships, consideration and desire for collaboration significantly inform and enrich these women writers' work, where the aspiration to pay tribute to another author and to her literary, personal and social accomplishments are skilfully articulated. Each writer becomes a model for the other and takes full advantage of her poetry to advertise her friendship, her literary connections, and, of course, to proclaim her admiration for her colleague. Moreover, the four sonnets indeed reveal the importance of female support, something that Domenichi might have already envisioned as his endeavours as collector and editor of an anthology of women poets demonstrate.

The four poets' yearning to imagine their reader, to enlighten, educate, and convince their interlocutor moves the lyric conversation forward, and powerfully carries on the dialogic flow which progresses throughout the anthology. These women were very much interested in writing for and to women, and in being read by women, an interest that would undoubtedly disperse any feeling of isolation. This strong desire for female approbation, models, readership, and friendship is expressed across the pages, and is reiterated and echoed in various words and styles. In her ground-breaking book Sappho in Early Modern England. Female Same-Sex Literary Erotics, Harriette Andrealis shows how and why it was traditionally hard to speak about same-sex relationships among women in the early modern period, a phenomenon that she labels the "erotics of unnaming" (2). Andrealis has observed that, "In spite of the availability of this sexual knowledge in Latin medical and other texts, a process of the 'unnaming' of female sexuality was simultaneously taking place in the real world of male medical manipulations of the female body," (17) a phenomenon which influenced other fields, such as literature. Moreover, she adds that how women poets of the early-modern period gave their feelings for one another verbal form "is an expression of their cultural embeddedness in historically variable understandings and definitions of erotic behavior" which varied according to social class, and geographic location (22). Domenichi's layout of the 1559 anthology allowed women to express feelings in concrete and poetic verbal form, thereby encouraging female relationships, without the scrutiny or 
negative labelling, rather simply nurturing a community of letters in which intimate comradeship could be expressed, mentoring articulated, and lyrical gifts encouraged. Thus, a close analysis of poems by women to women might unveil layers of meaning of erotic behaviour expressed in sixteenthcentury conventional language and imagery.

In the above four sonnets, the sensual frisson is a passionate intellectual admiration, skilfully expressed as writer and reader encounter sheer pleasure and excitement in writing and reading each other, and in including one another in their intimate poems. Indeed, Eisenbichler's term is very valuable in describing this enthusiastic intellectual and spiritual kinship which connects the many réseaux of the anthology, a kinship that earlymodern women writers had to pursue and conquer, as in a true love conquest. Even among less experienced and less-known writers such as Petrucci and Figliucci, the desire to address, emulate and encourage one another gives the reader a frank and exhilarating sense of intellectual and spiritual confidence.

Finally, the ways in which, and the reasons why women addressed women in their poetry can inform us of the many dimensions that we have yet to explore and understand about the complex cultural circumstances of their work. As Smarr suggests: "The importance of women writers for each other is an area deserving of considerable further attention. Certainly women, including poets, writing during the sixteenth century continually referred to each other as fortifying examples for their own enterprise. Surely they had a considerable interest not only in knowing each other's names but also in acquainting themselves with each other's writings when possible" (128). The poems we analyzed, and Domenichi's anthology in its entirety, fully show to what extent early -modern women authors yearned to read and emulate each other; how they dared to imagine their female readership and to impress it, and how all of this provided an indispensable source of cultural resources for them. Their connections with men such as their editor and his friends capable of understanding, appreciating, and promoting women's worth was as important as their connections with other women of shared literary and intellectual interests. By addressing and dedicating poems to one another they created and validated each other on paper, thus writing each other into existence. Their poems were shaped by other poems, and as they were in the company of a trusted friend, their dialogue was more open and at ease. Women wrote, addressed, and dedicated their work to other women writers because they wished to show the importance of their work to each other, thereby joining their efforts in making it more mainstream and in interweaving themselves in the tradition as writers and viable contributors of literary communities. By includ- 
ing and acknowledging one another, they validated their work, expanded their readership, and nurtured very important dialogues and friendships. Although some of the poems in the anthology acknowledged the importance of male support for the authors' own stepping out into print, most poems were dedicated to other female poets, encouraging as well as celebrating friendships among learned women. The 1559 anthology materializes how women writers could draw consciously from each other's poetry quite as much as from earlier or contemporary men's work. These poems became sources for future women writers as in Colonna's and Gambara's case, who became great models for literary women who followed in their footsteps. As Veronica Gambara so eloquently sang:

"Il sesso nostro un sacro, \& nobil tempio

Dovria, come gia a Palla, e Febo, farvi

Di ricchi marmi, e di finísim’oro."

(Our sex should raise a sacred and noble temple to you, rich in marble and finest gold, as was already done for Pallas and Phoebus).

(Rime d'alcune donne, 149)

\section{The University of Michigan - DeArborn}

\section{Cited Works}

Andrealis, Harriette. Sappho in Early Modern England. Female Same-Sex Literary Erotics 1550-1714. Chicago: University of Chicago Press, 2001.

Bandini Buti, Maria. Poetesse e scrittrici. Rome: Tosi, 1946. 130-131.

Brundin, Abigail. Vittoria Colonna and the Spiritual Poetics of the Italian Reformation. Aldershot, UK: Ashgate, 2008.

Campbell, Julie D. Literary Circles and Gender in Early Modern Europe. Aldershot, UK: Ashgate, 2006.

Clubb, Louise George and William G. Clubb. "Building a Lyric Canon: Gabriel Giolito and the Rival Anthologists, 1545-1590.” Italica 68:3 (1991): 332-344. Colonna, Vittoria. Rime. Edited by Alan Bullock. Rome: Laterza, 1982. Carteggio. Eds. Ermanno Ferrero and Giuseppe Müller. $2^{\text {nd }}$ ed. Turin: Loescher, 1892.

Cox, Virginia. Women's Writing in Italy 1400-1650. Baltimore: The Johns Hopkins University Press, 2008.

. "Women Writers and the Canon in Sixteenth-Century Italy. The Case of Vittoria Colonna." In Strong Voices, Weak History. Eds. Pamela Joseph Benson and Victoria Kirkham. Ann Arbor: University of Michigan Press, 2005, 14-31.

Domenichi, Lodovico (ed.). Rime diverse d'alcune nobilissime et virtuosissime donne. 
Lucca : Vincenzo Busdrago, 1559.

La nobiltà delle donne. Venice: Gabriel Giolito, 1549.

Eisenbichler, Konrad. "Laudomia Forteguerri Loves Margaret of Austria." In Same Sex Love and Desire Among Women in the Middle Ages. Eds. Francesca Canadé Sautman and Pamela Sheingorn. New York: Palgrave, 2001, 277-304.

Gambara, Veronica. Rime. Ed. Alan Bullock. Florence: Olschki, 1995.

Gibaldi, Joseph. "Vittoria Colonna: Child, Woman and Poet." In Women Writers of the Renaissance and Reformation. Ed. Katharina M. Wilson. Athens, GA: The University of Georgia Press, 1987, 22-46.

Jones, Ann Rosalind. The Currency of Eros: Women's Love Lyric in Europe, 15401620. Bloomington: Indiana University Press, 1990.

. "Surprising Fame: Renaissance Gender Ideologies and Women's Lyric." In The Poetics of Gender. Ed. Nancy Miller. New York : Columbia University Press, 1986, 74-95.

Labé, Louise. Euvres complètes. Ed. François Rigolot. Paris : Flammarion, 1986.

Larsen, Anne R. “'Un honneste passetems': Strategies of Legitimation in French Renaissance Women's Prefaces.” L'Esprit créateur 30:4 (1990):11-23.

Losse, Deborah N. "Women Addressing Women. The Differentiated Text." In Renaissance Women Writers. French Texts/American Contexts. Eds. Anne R. Larsen and Colette H. Winn. Detroit: Wayne State University, 1994, 23-37.

Piéjus, Marie-Françoise. "La première anthologie de poèmes féminins: l'écriture filtrée et orientée." In Le pouvoir et la plume; incitation, contrôle et répression dans l'Italie du XVIe siècle. Paris: Université de la Sorbonne Nouvelle, 1982, 193-213.

. "Lecture et écriture selon des anthologies poétiques au XVIe siècle en Italie." In L'écrivain face à son public en France et en Italie à la Renaissance. Eds. Charles Adelin Fiorato and J.-C. Margolin. Paris : Librairie Philosophique J. Vrin, 1989, 337-358.

Piscini, Angela. "Domenichi, Lodovico." In Dizionario biografico degli Italiani. Rome: Istituto dell'Enciclopedia Italiana, 1991, vol. 40, 595-600.

Poss, Richard. "Veronica Gàmbara: A Renaissance gentildonna." In Women Writers of the Renaissance and Reformation. Ed. Katharina M. Wilson. Athens: GA: The University of Georgia Press, 1987, 47-65.

Puga, María Luisa Cerrón. "Materiales para la construcción del canon petrarquista: las antologías de Rime (libri I-IX).” In Critica del testo. Rome: Viella, 1988, 249-290.

Robin, Diana. Publishing Women. Salons, the Presses, and the Counter-Reformation in Sixteenth-Century Italy. Chicago: University of Chicago Press, 2007.

Rigolot, François. "Discours liminaire et identité littéraire." Versants 15 (1989): 75-98.

Russell, Rinaldina. "Veronica Gambara.” In Italian Women Writers. Ed. R. Russell. Westport, CT, and London: Greenwood Press, 1994, 145-153.

Shemek, Deanna. "The Collector's Cabinet. Lodovico Domenichi's Gallery of Women.” In Strong Voices, Weak History. Eds. Pamela Joseph Benson and Victoria Kirkham. Ann Arbor: University of Michigan Press, 2005, 239-262. 
Smarr, Levarie Janet. Joining the Conversation. Dialogues by Renaissance Women. Ann Arbor: University of Michigan Press, 2005.

Stortoni, Laura Anna and Mary Prentice Lillie (eds. and trans.). Women Poets of the Italian Renaissance. Courtly Ladies and Courtesans. New York: Italica Press, 1997.

Tomasi, Franco. "Alcuni aspetti delle antologie liriche del secondo Cinquecento." In I più vaghi e i più soavi fiori. Studi sulle antologie di lirica del Cinquecento. Eds. Monica Bianco and Elena Strada. Alessandria: Edizioni dell'Orso, 2001, 97-111. 
